\title{
Environmental factors influencing the occurrence of alien mollusks in semi-arid reservoirs
}

\author{
Franciely Ferreira Paiva ${ }^{1, *}$, Wilma Izabelly Ananias Gomes², Carlinda Raílly Medeiros ${ }^{3}$, \\ Érica Luana Ferreira Álvaro ${ }^{4}$, Iara Maria Santos Ribeiro ${ }^{4}$ and Joseline Molozzi ${ }^{5}$
}

1 Pós-Graduação em Ecologia e Conservação - Universidade Estadual da Paraíba, Campina Grande, Brazil.

2 Pós-Graduação em Ciência e Tecnologia Ambiental - Universidade Estadual da Paraíba, Campina Grande, Brazil.

3 Pós-Graduação em Ecologia - Universidade Federal do Pará, Belém, Brazil.

${ }^{4}$ Graduação em Ciências Biológicas - Universidade Estadual da Paraíba, Campina Grande, Brazil.

5 Departamento de Biologia; Programa de Pós-Graduação em Ecologia e Conservação-Universidade Estadual da Paraíba, Campina Grande, Brazil.

* Corresponding author: fran.paiva@outlook.com.br

Received: $13 / 09 / 17 \quad$ Accepted: 18/01/18

\begin{abstract}
Environmental factors influencing the occurrence of alien mollusks in semi-arid reservoirs

We assessed which environmental variables had the greatest influence on the occurrence of alien mollusks in reservoirs in the semi-arid region of Brazil during periods of drought. The study was conducted in the Argemiro de Figueiredo, Epitácio Pessoa, and Poções reservoirs in the Paraíba River watershed in northeastern Brazil during July and October/2015. Sampling was undertaken in three regions in each reservoir: 1) near the inflow from the principal tributary; 2) the mid-reservoir section; and, 3 ) near the dam. Three sampling sites were established in each reservoir region. The physical and chemical parameters of the reservoir waters in each site were measured and the granulometric compositions of their sediments determined. A total of 8635 benthic individuals were identified, of which 6569 were alien mollusks. Alien mollusks represented $90 \%$ of all individuals collected from the benthic community in the Argemiro de Figueiredo reservoir, 63 \% in Epitácio Pessoa, and 35 \% in Poções. Melanoides tuberculata (6283 individuals) was the most abundant mollusk species, followed by Corbicula largillierti (286 individuals). Significant differences were observed in terms of the abundances of alien mollusks in the different reservoirs $(p=0.0001)$ and during the different sampling periods $(p=0.0001)$, but not among the different sampling sites in each reservoir $(p=0.937)$. In terms of environmental parameters, significant differences were observed in the different reservoirs $(p=0.0001)$, but not in the different sampling sites in each $(p=0.7428)$ or during the different samplings periods $(p=0.346)$. The Best model $\left(\mathrm{R}^{2}=0.61\right)$ selected five predictor variables for the occurrence of alien mollusks: total nitrogen, salinity, temperature, gravel, and silt. Environmental variables, together with periods of severe drought and the natural characteristics of the region (such as the mineral composition of the soils) favored the occurrence of alien mollusks in semi-arid reservoirs.
\end{abstract}

Key words: alien species, aquatic ecosystems, semi-arid region, period of drought

\section{RESUMO}

\section{Fatores ambientais influenciando a ocorrência de moluscos exóticos em reservatórios semiáridos}

O objetivo deste estudo foi avaliar quais variáveis ambientais têm maior influência na ocorrência de moluscos exóticos em reservatórios do semiárido em periodo de seca. Este estudo foi realizado nos reservatórios de Argemiro de Figueiredo, Epitácio Pessoa e Poções, bacia hidrográfica do Rio Paraíba / Brasil, nos meses de julho e outubro de 2015. Em cada reservatório, as amostragens foram realizadas em três regiões: 1) perto da entrada do principal afluente; 2) a seção do meio reservatório; e, 3) perto da barragem. Para cada região foram estabelecidos três locais de amostragem. Os parâmetros fisicos e químicos da água foram medidos, bem como a composição granulométrica do sedimento foi estimada em cada local. Foram identificados 8635 indivíduos bentônicos, sendo 6569 moluscos exóticos. No Argemiro de Figueiredo os moluscos exóticos 
representam $90 \%$, Epitácio Pessoa $63 \%$ e Poções $35 \%$ da comunidade bentônica. Melanoides tuberculata (6283 indivíduos) foi a espécie mais abundante, seguida de Corbicula largillierti (286 indivíduos). Diferenças significativas foram observadas para a abundância de espécies exóticas entre os reservatórios $(\mathrm{p}=0.0001)$ e entre os periodos de amostragem $(\mathrm{p}=0.0001)$, não sendo observado o mesmo para as regiões $(\mathrm{p}=0.937)$. Para os parâmetros ambientais, houve diferenças significativas entre os reservatórios $(\mathrm{p}=0.0001)$, mas não para as regiões $(\mathrm{p}=0.7428)$ e os periodos de amostragem $(p=0.346)$. O modelo Best $\left(R^{2}=0.61\right)$ selecionou cinco variáveis preditoras para a ocorrência de moluscos exóticos: nitrogênio total, salinidade, temperatura, cascalho e silte. As variáveis ambientais, juntamente com periodos de maior seca e características naturais da região, (como a composição mineral dos solos), favorecem a ocorrência de moluscos exóticos em reservatórios do semiárido.

Palavras chave: espécies exóticas, ecossistemas aquáticos, região semiárida, periodo de seca

\section{INTRODUCTION}

Aquatic ecosystems are highly threatened globally due to pressure from human population and industrial growth (Mustapha, 2008). Populational growth has resulted in the expansion of agriculture, industry, trade, and energy production, all of which can lead to environmental and ecological impacts intensified by management inefficiencies and poor conservation policies for water resources (Mishra \& Singh, 2010).

Among the main problems facing aquatic ecosystems today is the introduction of alien species, which threaten biodiversity and impact ecosystem dynamics (Rocha et al., 2005). Alien species are considered the second greatest cause of biodiversity losses globally (CDB, 2001). The phylum Mollusca has the greatest number of recorded aquatic invasions in innumerable locations throughout the world (Lucca, 2012).

The main forms of dispersal of alien mollusk species are accidental seeding associated with commerce (Silva et al., 1994) and their transport in the ballast waters and sediments of oceangoing freighters (Alonso \& Castro-Díez, 2014). Others possible forms of introduction may involve migratory birds or due to their economic importance (Thiengo et al., 2006).

Alien mollusk species demonstrate biological traits (e.g., high competitive and reproductive capacities) that can disrupt trophic structures and biological interactions among the native fauna (Ricciardi \& Macisaac, 2000). Their high abundance (high invasive potential) can result in the reduction, or even exclusion, of native species, resulting in biotic homogenization (Alonso \& Castro-Díez, 2014).

The mollusk Corbicula largillierti (Philippe,
$1844)$ is an Asiatic species that has invaded various regions of South America (Mansur et al., 2004). It was first recorded in Brazil in the Pantanal region of Mato Grosso State (Callid \& Mansur, 2002) and later in a reservoir in the watershed of the Paraíba River in the semi-arid region of that country, principally in sites near to input the tributaries of that river (Azevêdo et al., 2014)

Another alien species of wide distribution is the mollusk Melanoides tuberculata (Müller, 1774) (Silva \& Barros, 2011) of Afro-Asian origin (Malek \& Cheng, 1974). It was first recorded (1967) in Brazil in the city of Santos, in São Paulo State (Vaz et al., 1986). A study undertaken by Santos et al. (2010) in reservoirs in the semi-arid region of that country emphasized that eutrophic conditions are favorable to the establishment of $M$. tuberculata.

Both $M$. tuberculata and $C$. largillierti are considered "r strategist" species, demonstrating parthenogenetic reproduction, incubation of their embryos, and the behavioral habit of burying themselves in the substrate to avoid dissection; those adaptive characteristics lend them distinct advantages in responding to abiotic and biotic disturbances in aquatic ecosystems, and give them with greater chances of successful colonization (Pointier et al., 1994; Marco, 1999; Martins- Silva \& Barros, 2001; Da Silva Martins et al., 2006).

Aquatic ecosystems in the semi-arid region present significant potential for the establishment of high densities of alien species due to their abiotic characteristics (long periods of drought, high temperatures, and high rates of evaporation) that decrease niche availability for native species (Abílio et al., 2007; Eskinazi Sant'Anna, 2007; Mustapha, 2008). Studies undertaken in semi-arid reservoirs by Abílio et al. (2006 and 2007) 
Table 1. Characterization of Argemiro de Figueiredo, Epitácio Pessoa and Poções reservoirs, Paraíba River watershed, Paraíba/Brazil. Data provided by Agência Executiva de Gestão das Águas do Estado da Paraíba (AESA 2016). Caracterização dos reservatórios de Argemiro de Figueiredo, Epitácio Pessoa e Poções, bacia do Rio Paraíba, Paraíba/Brasil. Dados fornecidos pela Agência Executiva de Gestão das Águas do Estado da Paraíba (AESA 2016).

\begin{tabular}{lccc}
\hline Features /Reservoirs & $\begin{array}{c}\text { Argemiro de } \\
\text { Figueiredo }\end{array}$ & Epitácio Pessoa & Poções \\
\hline Geographic localization & $7^{\circ} 27,5^{\prime} 3^{\prime \prime} \mathrm{S}$ & $7^{\circ} 29^{\prime} 20^{\prime \prime} \mathrm{S}$ & $7^{\circ} 53^{\prime} 38^{\prime \prime} \mathrm{S} \mathrm{e}$ \\
Altitude (m) & $35^{\circ} 35^{\prime} 52,6^{\prime \prime} \mathrm{W}$ & $36^{\circ} 17^{\prime} 3^{\prime \prime} \mathrm{W}$ & $37^{\circ} 0{ }^{\prime} 30^{\prime} \mathrm{W}$ \\
City & 45 & 355 & 596 \\
Construction year & Itatuba & Boqueirão & Monteiro \\
Retention time (year) & 2002 & 1957 & 1982 \\
Main finality & 6 & 6 & 7 \\
& Supply, irrigation and & Supply and & Supply and \\
& pisciculture & irrigation & irrigation \\
\hline
\end{tabular}

revealed that the occurrence of alien mollusks was correlated with high salinity, high concentrations of nitrate, phosphorus and total dissolved solids, and an alkaline $\mathrm{pH}$.

It is therefore of fundamental importance to determine which environmental variables influence the occurrence of alien mollusks in semi-arid region reservoirs during periods of drought. This information will aid in the implementation of monitoring programs for their management and for the conservation of those aquatic ecosystems.

\section{MATERIAL AND METHODS}

\section{Study area and sampling design}

The present study was undertaken in the Argemiro de Figueiredo, Epitácio Pessoa, and Poções reservoirs, described in Table 1 , located in the Paraíba River watershed (651'31"- 8²6'21" S and 34 48'35" - 37'2'15" W) in Paraíba State, Brazil (Fig. 1). The Paraíba River watershed is the second largest in that state, encompassing 20 $071.83 \mathrm{~km}^{2}$ and $52 \%$ of the state's inhabitants (AESA, 2016). The watershed is included in a mega-project for the transposition of the waters of the São Francisco River to the dry northeastern region of Brazil, with the Poções reservoir serving as the eastern axis of that integration. The predominant climate in the region is hot and semi-arid (BSh, according to the Köppen-Geiger classification), with a dry season of from 9 to 10 months a year, with mean annual rainfall of 400 mm (Alvares et al., 2013). Data related to the maximum water storage capacities and average water volumes of the reservoirs were obtained from the Agência Executiva de Gestão das Águas/AESA (www.aesa.pb.gov.br).

Sampling was conducted in each reservoir in three areas (near the inflow from the principal tributary, the mid-reservoir section and near the dam) (Fig. 1); three sites were sampled in each area, totaling nine sampling sites per reservoir. Sampling was undertaken in July and October/2015.

\section{Biological characterization}

To assess the compositions of the benthic macroinvertebrate communities, sediment samples were collected along the banks of the reservoirs using an Eckman-Birge dredge (area $225 \mathrm{~cm}^{2}$ ) that were fixed in situ with $10 \%$ formaldehyde and removed to the laboratory. The samples were subsequently washed in sieves (500 $\mu \mathrm{m}$ mesh) and any organisms encountered were identified by viewing under a stereomicroscope and consulting specialized identification keys (Ward \& Whipple, 1959; Hawking \& Smith, 1997; 


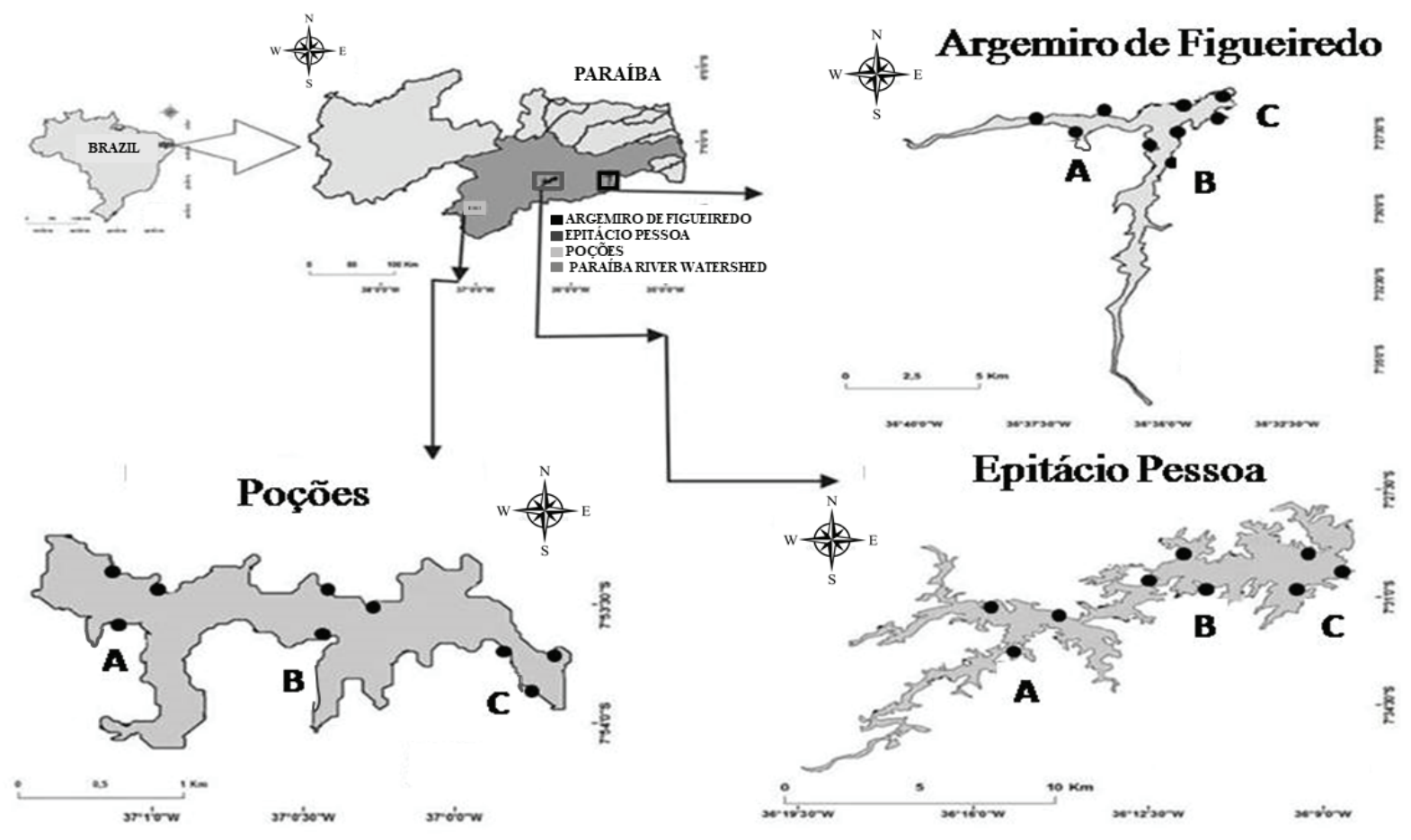

Figure 1. Sites of samplings distributed in the regions near to input of the main tributary (A), intermediary (B) and near to dam (C) of Argemiro de Figueiredo, Epitácio Pessoa and Poções reservoirs localized in Paraíba River watershed/Brazil. Sites de amostragens distribuídos nas regiões próximas à entrada do principal afluente (A), intermediária (B) e próximo da barragem (C) dos reservatórios Argemiro de Figueiredo, Epitácio Pessoa e Poções localizados na bacia hidrográfica do Rio Paraíba/Brasil.

Mugnai et al., 2010). Chironomidae larvae (Diptera, Insecta) were identified to the genus level (Trivinho-Strixino \& Strixino, 1995; Trivinho-Strixino, 2011) and alien mollusk species where identified to the species level (Mansur et al., 2004; Thompson, 2004; Pereira et al., 2012).

\section{Characterization of limnologic parameters}

The physical and chemical aspects of the water column were evaluated in each of the three regions of the reservoirs, measuring: temperature $\left({ }^{\circ} \mathrm{C}\right), \mathrm{pH}$, turbidity (NTU), dissolved oxygen $(\mathrm{mg} / \mathrm{L})$, and salinity (PPT) using a multiparameter probe (HORIBA U-50). One liter of water was also collected at each site to determine the concentrations of total phosphorus (PT $\mu \mathrm{g} / \mathrm{L})$ and total nitrogen $(\mathrm{NT} \mu \mathrm{g} / \mathrm{L})$, following the "Standard Methods for the Examination of Water and Waste-water" (APHA, 2005). The analyses of total alkalinity were performed following Mackereth et al. (1978).

\section{Granulometric composition of sediment}

Samples of sediment with size of $225 \mathrm{~cm}^{2}$ were collected from each sampling site to characterize the granulometric composition of each site. The material was processed in the laboratory according to the methodology described by Suguio (1973) and modified by Callisto and Esteves (1996). The samples were dried at $60{ }^{\circ} \mathrm{C}$ for 72 hours and subsequently agitated in sieves to separate and classify the particles: gravel $(>1000 \mu \mathrm{m})$; coarse sand (500-1000 $\mu \mathrm{m})$; middle sand (250-500 $\mu \mathrm{m})$; fine sand $(63-250 \mu \mathrm{m})$ and silt $(<63 \mu \mathrm{m})$.

\section{Data analysis}

All the analyses were performed considering only alien mollusk species. Permutational Multivariate Analysis of Variance (PERMANOVA) was used to assess any differences in the abundances of alien mollusks in the different regions of the reservoirs and between the different reservoirs 
Table 2. Maximum capacity, atual volume and abundance of alien mollusks species collected in the periods of July and October in Argemiro de Figueiredo, Epitácio Pessoa and Poções reservoirs, Paraiba River watershed/ Brazil. Source of the data: Agência Executiva de Gestão das Águas do Estado da Paraíba (AESA 2016). Capacidade máxima, volume atual e abundância de espécies de moluscos exóticos coletados nos períodos de julho e outubro nos reservatórios Argemiro de Figueiredo, Epitácio Pessoa e Poções, bacia hidrográfica do Rio Paraíba/Brasil. Fonte dos dados: Agência Executiva de Gestão das Águas do Estado da Paraíba (AESA 2016).

\begin{tabular}{|c|c|c|c|c|c|}
\hline \multirow[b]{2}{*}{ Reservoirs } & \multirow[b]{2}{*}{$\begin{array}{c}\text { Maximum } \\
\text { capacity }\left(\mathrm{m}^{3}\right)\end{array}$} & \multicolumn{2}{|c|}{ July } & \multicolumn{2}{|c|}{ October } \\
\hline & & $\begin{array}{c}\text { Volume in } \\
\text { the period } \\
\left(\mathrm{m}^{3}\right)\end{array}$ & $\begin{array}{l}\text { Abundance } \\
\text { exotic } \\
\text { molluscs }\end{array}$ & $\begin{array}{l}\text { Volume in the } \\
\text { period }\left(\mathrm{m}^{3}\right)\end{array}$ & $\begin{array}{c}\text { Abundance } \\
\text { exotic } \\
\text { molluscs } \\
\end{array}$ \\
\hline $\begin{array}{l}\text { Argemiro de } \\
\text { Figueiredo }\end{array}$ & 253000000 & $\begin{array}{c}41429817 \\
(16 \%)\end{array}$ & 2525 & $\begin{array}{c}38165443 \\
(15 \%)\end{array}$ & 1860 \\
\hline Epitácio Pessoa & 411686287 & $\begin{array}{c}71122389 \\
(17 \%)\end{array}$ & 977 & $\begin{array}{c}58829024 \\
(14 \%)\end{array}$ & 601 \\
\hline Poções & 29861562 & $\begin{array}{c}550255 \\
(2 \%)\end{array}$ & 568 & $\begin{array}{c}223588 \\
(1 \%)\end{array}$ & 38 \\
\hline
\end{tabular}

studied (Anderson et al., 2008). Differences in the total abundances of the mollusks during the different sampling periods considered only two independent variables (months) for each reservoir, using the chi-square test. That test measures the degree to which the observed frequencies differ from expected frequencies, under the null hypothesis of independence. Differences in environmental parameters between the different sites, reservoirs, and sampling periods were also assessed using PERMANOVA analysis, considering 9999 permutations (Anderson, 2001; Anderson et al., 2008). Three fixed factors were consid- ered: sites (three levels: near the inflow from the principal tributary, the mid-reservoir section and near the dam), reservoirs (three levels: Argemiro de Figueiredo, Epitácio Pessoa, and Poções), and periods (two levels: July and October). The environmental data were previously $\log x+1$ transformed and normalized. The abundance data were square root transformed, and Bray-Curtis was used as measure of similarity.

Distance-based linear models (DISTLM) were used to verify which environmental variables were predictors for the abundance of exotic mollusk species in the different sampling periods

Table 3. Values of the Qui-square test for comparison of the total abundance of alien mollusks species between the periods of sampling in Argemiro de Figueiredo, Epitácio Pessoa and Poções reservoirs, Paraiba River watershed/Brazil (significant values $p<0.05)$. Valores do teste Qui-quadrado para comparação da abundância total das espécies de moluscos exóticos entre os períodos de amostragem nos reservatórios Argemiro de Figueiredo, Epitácio Pessoa e Poções, bacia do Rio Paraíba/Brasil (valores significativos $\mathrm{p}<0.05)$.

\begin{tabular}{lccc}
\hline \multicolumn{1}{c}{ Reservoirs } & Qui-square & $\begin{array}{c}\text { Degree of } \\
\text { freedom }\end{array}$ & $\boldsymbol{P}$ \\
\hline Argemiro de Figueiredo & 100849 & 1 & $<0.0001$ \\
Epitácio Pessoa & 89592 & 1 & $<0.0001$ \\
Poções & 463531 & 1 & $<0.0001$ \\
\hline
\end{tabular}


Table 4. Average and pattern deviation of the environmental variables measured in July and October 2015, in the Argemiro de Figueiredo, Epitácio Pessoa and Poções reservoirs, Paraíba River watershed/Brazil. Desvio padrão e media das variáveis ambientais medidas em julho e outubro de 2015, nos reservatórios Argemiro de Figueiredo, Epitácio Pessoa e Poções, bacia do Rio Paraíba/Brasil.

\begin{tabular}{lcccccc}
\hline \multirow{2}{*}{$\begin{array}{l}\text { Environmental } \\
\text { Parameters }\end{array}$} & \multicolumn{2}{c}{ Argemiro de Figueiredo } & \multicolumn{2}{c}{ Epitácio Pessoa } & \multicolumn{2}{c}{ Poções } \\
\cline { 2 - 7 } & July & October & July & October & July & October \\
\hline Temperature $\left({ }^{\circ} \mathrm{C}\right)$ & $25.48 \pm 0.18$ & $26.53 \pm 0.33$ & $24.52 \pm 0.53$ & $24.86 \pm 0.43$ & $22.65 \pm 0.45$ & $23.33 \pm 0.50$ \\
Total Phosphorus $(\mu \mathrm{g} / \mathrm{L})$ & $90.61 \pm 30.17$ & $58.67 \pm 7.5$ & $83.11 \pm 45.78$ & $93.67 \pm 28.48$ & $615.89 \pm 17.82$ & $805.33 \pm 12.52$ \\
Total Nitrogen $(\mu \mathrm{g} / \mathrm{L})$ & $199.04 \pm 51.79$ & $185.98 \pm 10.86$ & $196.06 \pm 87.84$ & $136.32 \pm 20.25$ & $418.79 \pm 82.77$ & $491.32 \pm 161.90$ \\
pH & $9.97 \pm 0.08$ & $10.30 \pm 0.10$ & $10.08 \pm 0.20$ & $10.36 \pm 0.26$ & $10.42 \pm 0.07$ & $10.26 \pm 0.05$ \\
Alkalinity $(\mu \mathrm{g} / \mathrm{L})$ & $3.23 \pm 0.20$ & $4.06 \pm 0.56$ & $3.72 \pm 0.23$ & $2.22 \pm 0.10$ & $10.61 \pm 0.54$ & $3.73 \pm 0.12$ \\
Salinity $(\mathrm{PPT})$ & $0.13 \pm 0.00$ & $0.14 \pm 0.00$ & $0.09 \pm 0.00$ & $0.10 \pm 0.00$ & $0.26 \pm 0.00$ & $0.42 \pm 0.00$ \\
Turbidity $(\mathrm{NTU})$ & $84.80 \pm 48.74$ & $194.08 \pm 179.26$ & $39.73 \pm 20.17$ & $97.38 \pm 48.40$ & $269.44 \pm 13.21$ & $809.67 \pm 38$ \\
Dissolved Oxygen $(\mu \mathrm{g} / \mathrm{L})$ & $13.60 \pm 15.64$ & $7.16 \pm 0.74$ & $8.13 \pm 0.32$ & $6.75 \pm 1.00$ & $3.60 \pm 0.59$ & $8.00 \pm 2.64$ \\
Gravel \% & $9.61 \pm 2.46$ & $20.76 \pm 5.27$ & $5.43 \pm 8.16$ & $6.84 \pm 6.05$ & $13.68 \pm 1.96$ & $2.70 \pm 3.54$ \\
Coarse sand \% & $9.67 \pm 4.05$ & $22.28 \pm 5.96$ & $13.50 \pm 8.03$ & $14.62 \pm 11.84$ & $20.24 \pm 12.03$ & $14.39 \pm 9.42$ \\
Middle sand \% & $24.27 \pm 2.46$ & $16.86 \pm 0.61$ & $34.45 \pm 5.55$ & $29.52 \pm 5.43$ & $12.19 \pm 6$ & $28.36 \pm 6.44$ \\
Fine sand \% & $29.69 \pm 2.71$ & $24.16 \pm 6.83$ & $26.70 \pm 3.59$ & $25.32 \pm 4.63$ & $28.80 \pm 15.90$ & $29.00 \pm 7.30$ \\
Silt \% & $20.09 \pm 4.43$ & $8.90 \pm 3.91$ & $14.67 \pm 3.48$ & $17.76 \pm 5.94$ & $20.08 \pm 4.45$ & $18.87 \pm 1.72$ \\
Mud \% & $6.67 \pm 1.43$ & $7.05 \pm 8.00$ & $5.24 \pm 1.54$ & $5.73 \pm 1.50$ & $5.00 \pm 1.94$ & $7.90 \pm 3.84$ \\
\hline
\end{tabular}

(Legendre \& Anderson, 1999). That method verifies and models the relationships between a cloud of multivariate data for one or more predictive variable (Anderson et al., 2008). The DISTLM routine was employed using the BEST criterion and the values of the coefficients of AIC determinations. Distance-based redundancy analysis (dbRDA) was used for visual interpretation of the relationships between the environmental variables selected by DISTLM and the alien mollusk species (Anderson et al., 2008).

The PERMANOVA, DISTLM, and dbRDA statistical analyses were performed using PRIMER + PERMANOVA 6.0 software (Anderson et al., 2008). The chi-square tests were performed using the Bioestat 5.0 program.

\section{RESULTS}

Were collected 8635 organisms during the study that were distributed among 17 taxa (6 Diptera, 4
Mollusca, 2 Ephemeroptera, 2 Odonata, 1 Annelida, 1 Crustacea, and 1 Tubellaria), including 6569 alien mollusks. Melanoides tuberculata was the most abundant alien mollusk species in the three reservoirs sampled: Argemiro de Figueiredo (4385 individuals, $90 \%$ of the total number of organisms); Epitácio Pessoa (1292 individuals, 63 $\%$ of the total number of organisms); and Poções (606 individuals, $35 \%$ of the total number of organisms). Corbicula largillierti was recorded only in the Epitácio Pessoa reservoir (286 individuals, $14 \%$ of the total number of organisms).

Significant differences were observed in terms of the abundances of alien mollusk species in the different reservoirs (PERMANOVA: Pseudo- $\left.\mathrm{F}_{2.39}=20.065 ; p=0.0001\right)$; there were no significant differences, however, between the different sites within each reservoir (PERMANOVA: Pseudo- $\left.\mathrm{F}_{2.39}=0.2589 ; p=0.937\right)$. We noted decreases in the abundances of alien mollusks in all reservoirs from July to October: a $28 \%$ decrease in 


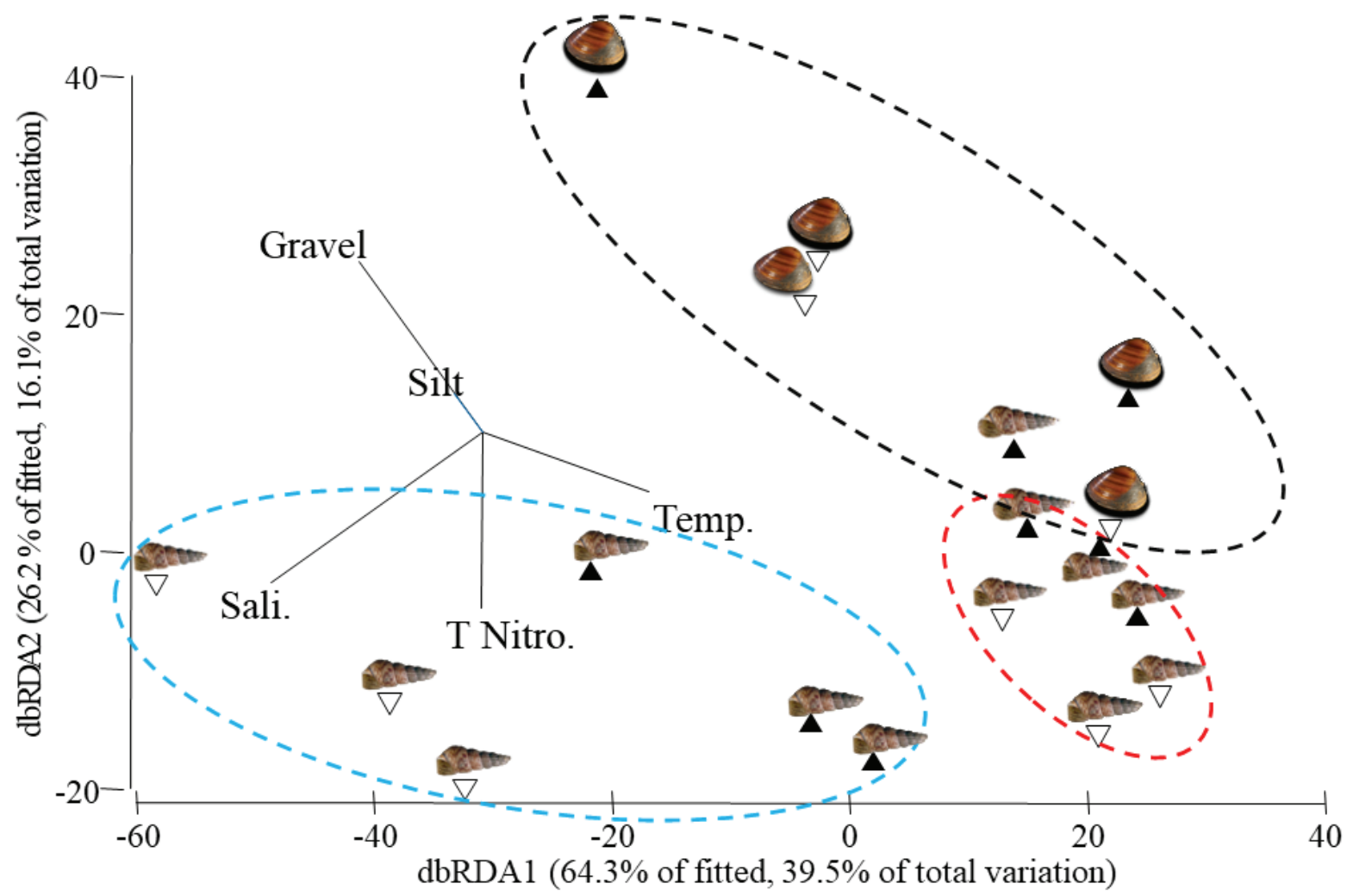

Figure 2. "Distance-based redundancy analysis" (dbRDA) based in abundance of the alien mollusks species in function of predictors variables selected by DISTLM in Argemiro de Figueiredo, Epitácio Pessoa and Poções reservoirs, Paraíba River watershed/ Brazil. Where: Blue ellipse Poções, red ellipse Argemiro de Figueiredo and black ellipse Epitácio Pessoa. Black Triangles: July, White Triangles: October. "Análise de redundância baseada em distância" (dbRDA) com base na abundância de espécies de moluscos exóticos em função de variáveis preditoras selecionadas pela DISTLM nos reservatórios Argemiro de Figueiredo, Epitácio Pessoa e Poções, bacia hidrográfica do Rio Paraíba/Brasil. Onde: Elipse azul Poções, elipse vermelha Argemiro de Figueiredo e elipse preta Epitácio Pessoa. Triângulos pretos: julho, triângulos brancos: outubro.

Argemiro de Figueiredo, $40 \%$ in Epitácio Pessoa, and $94 \%$ in Poções. Those reductions coincided with decreases in the water volumes of those reservoirs, as can be seen in Table 2. Significant differences were observed for the abundance of alien mollusks species in each reservoir during the periods of sampling $(p=0.0001)$, as shown in Table 3.

Regarding environmental parameters, significant differences were observed among all reservoirs (PERMANOVA: Pseudo- $\mathrm{F}_{2.17}=5.2731$; $p=0.0001)$. The variations in the environmental parameters of the three different reservoirs are presented in Table 4. The highest salinity $(0.42 \pm 0.00)$ and highest total nitrogen $(491.2 \pm 161.90)$ values were found in the Poções reservoir; the lowest values were encountered in the Epitácio Pessoa reservoir $(0.09 \pm 0.00$ and $136.32 \pm 20.25$ respectively). In terms of granulometric composition, coarse sand, middle sand, fine sand, and silt were most representative categories in the three reservoirs. Those differences were not observed in the different regions of the reservoirs (PERMANOVA: Pseudo- $\mathrm{F}_{2.17}=0.7209 ; p=0.7428$ ), or during the different sampling periods (PERMANOVA: Pseudo- $\mathrm{F}_{1.17}=1.0647 ; p=0.346$ ).

The Best model $\left(\mathrm{R}^{2}=0.61\right)$ included five predictive variables for the abundance of alien mollusks species: salinity, temperature, total nitrogen, gravel and silt.

The two first axes of the dbRDA explained $90.5 \%$ of relationships observed in terms of the abundances of alien mollusks and the environ- 
mental variables, and $64.3 \%$ of the total variability of the abundance data of the alien mollusks (Fig. 2). The first axis of the dbRDA was correlated with the variables salinity (-0.711) and temperature (0.559); the second axis showed greater correlation with total nitrogen (-0.598) and gravel (0.572), as shown in table 5 .

\section{DISCUSSION}

The decreasing water volumes in the reservoirs during the course of the study negatively influenced the abundances of alien mollusk species, even though they demonstrated tolerance to various anthropic impacts and had the capacity to adapt to widely varying environmental conditions. Decreasing water volumes in the reservoirs apparently led to niche reductions and, consequently, to population reductions. A study undertaken by Azevêdo et al. (2015) in the same Poções reservoir likewise observed a reduction in the abundance of alien mollusks species during periods of low water volume.

The Poções reservoir demonstrated the lowest water volume among the different reservoirs studies, accompanied by higher salinity and total nitrogen concentrations, and a lower abundance of alien mollusk species, indicating that its environmental conditions were so adverse that not

Table 5. Results of the dbRDA for the environmental variables collected in period of July and October 2015, related with abundance of the alien mollusks species in Argemiro de Figueiredo, Epitácio Pessoa and Poções reservoirs, Paraíba River watershed. Resultados do dbRDA para as variáveis ambientais coletadas no periodo de julho e outubro de 2015, relacionadas com a abundância das espécies de moluscos exóticos nos reservatórios Argemiro de Figueiredo, Epitácio Pessoa e Poções, bacia hidrográfica do Rio Paraíba.

\begin{tabular}{lcc}
\hline \begin{tabular}{c} 
Environmental \\
\multicolumn{1}{c}{ Parameters }
\end{tabular} & $\mathbf{1}^{\mathbf{o}}$ axis & $\mathbf{2}^{\mathbf{o}}$ axis \\
\hline Salinity & -0.711 & -0.507 \\
Gravel & -0.416 & 0.572 \\
Total Nitrogen & -0.007 & -0.598 \\
Temperature & 0.559 & -0.204 \\
Silt & -0.095 & 0.129 \\
\hline
\end{tabular}

even the alien species Melanoides tuberculata, with its high invasive potential, was able to maintain a high abundance.

The mollusk Corbicula largillierti was only recorded in the Epitácio Pessoa reservoir. Although favorable conditions existed for its occurrence in the region as a whole, the isolation of the various reservoirs due to their long water retention times (approximately six years) may have restricted its dispersal through the watershed.

Among the limnological variables that exhibited correlations with the occurrence of alien mollusks species, we highlight the salinity. The high salinity levels encountered in the semi-arid region are related to the nature of the crystalline rocks found there, which are composed of minerals such as calcium, sodium, and magnesium (Porto et al., 1999). Among the minerals that leach from crystalline rocks, calcium salts are fundamental for the formation of mollusk shells (Marxen et al., 2003). At high concentrations, however, the presence of those salts in the reservoir water will demand greater energy expenditures by aquatic organisms to maintain their osmotic equilibria (Burton, 1983; Funakoshi et al., 1985; Cheng et al., 2002).

Another limnological variable that can influence the occurrence of alien mollusks is temperature, as it directly acts in controlling the speeds of the metabolic and physiological processes of aquatic species (Kinne, 1970; Newel \& Branch, 1980). Kock and Wolmarans (2009) noted that the high abundances of $M$. tuberculata and $C$. largillierti were related to environmental temperatures between $20-30{ }^{\circ} \mathrm{C}$, the ideal range for their reproduction (Reyna et al., 2013).

Nitrogen and phosphorus concentrations are considered the principal factors driving primary productivity in aquatic ecosystems, and higher concentrations provide more food resources for alien mollusk species that exhibit scraper feeding habits, mainly on the periphyton (Harper, 1992; Porter et al., 2008). The reservoir that exhibited the highest dissolved nutrient levels in the present study, however, demonstrated a lower abundance of alien species as compared to reservoirs with intermediary dissolved nutrient values. While alien mollusks are known to have wide tolerance amplitudes for highly impacted 


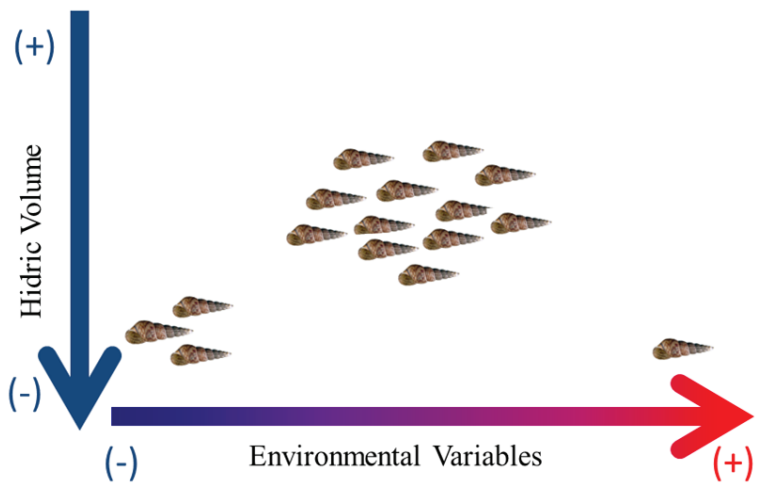

Figure 3. Schematic representation of the relationship between hydric volume, limnological variables and abundance of alien mollusks species observed for semi-arid region, Paraíba River watershed/Brazil. Representação esquemática da relação entre volume hídrico, variáveis limnológicas e abundância das espécies de moluscos exóticos observadas para a região semiárida, bacia do Rio Paraíba/Brasil.

environments, we believe that the decrease of water volumes that will become regulating factors of the abundance of exotic species according to Shelford's law (Fig. 3).

Decreasing water volumes also lead to habitat homogenization, with the sentiments in the focal reservoirs being predominately composed of fine particles. Habitats composed of larger particles (such as gravel) favor the availability of food resources, while sediments composed of smaller particles are less densely colonized by the periphyton (Fenoglio \& Cucco 2004). Torre and Reyna (2013) reported that $C$. largillierti will rapidly colonize sandy substrates, but as intraspecific competition increases, individuals will begin to colonize other (presumably less favorable) habitats.

The fact that we did not observe any significant differences in the abundances of alien species or the limnological variables in the three different sites examined in each reservoir is probably related to reductions in reservoir water volumes and their consequent homogenization (Thornton et al., 1990).

The results of the present study demonstrated that the environmental variables that influence the occurrence of alien mollusks are principally salinity, total nitrogen, temperature, and the substrates gravel and silt. Reservoir water volume reductions, however, represent the principal factor leading to the homogenization of limnological habitats, acting as a regulator of alien mollusk species abundances in reservoirs in the semi-arid region of Brazil.

\section{ACKNOWLEDGEMENTS}

The data presented here were gathered during the REHISA Project MCTI/FINEP CT-HIDRO 01/2013. The authors thank the Benthos Laboratory (UEPB) for their support in processing the material, and the Laboratory of Aquatic Ecology for logistic support.

\section{REFERENCES}

ABÍliO, F. J. P., A. A. F. GESSNER, R. L. LEITE, \& T. L. M. RUFFO. 2006. Gastrópodes e outros invertebrados do sedimento e associados a macrófita Eichhornia crassipes de um açude hipertrófico do semiárido paraibano. Revista de biologia e ciências da terra, 6, 165-178.

ABÍliO, F. J. P., T. L. M. RUFFO, A. H. F. F. SOUZA, H. S. FLORENTINO, J. E. T. OLIVEIRA, B. N. MEIRELES, \& A. C. D SANTANA. 2007. Macroinvertebrados bentônicos como bioindicadores de qualidade ambiental de corpos aquáticos da caatinga. Oecologia Brasiliensis, 11, (3), 397-409.

AGÊNCIA EXECUTIVA DE GESTÃO DAS ÁGUAS DO ESTADO DA PARAÍBA AESA. Comitê do Rio Paraíba [online]. 2016. [viewed 17 Agus. 2016]. Available from: www.aesa.pb.gov.br.

ALONSO, A. \& D. P. CASTRO. 2015. El caracol acuático neozelandês delcieno (Potamopyrgus antipodarum): impactos ecológicos y distribución de esta espécie exótica em la península ibérica. Ecossistemas, 24 (11), 52-58. DOI: 10.7818/ECOS.2015.24-1.09

ALVARES, C. A., J. L. STAPE, P. C. SENTELHAS, G. DE MORAES, J. LEONARDO \& G. SPAROVEK. 2013. Köppen's climate classification map for Brazil. Meteorologische Zeitschrift, 22 (6), 711-728. DOI: 10.1127/0941-2948/2013/0507

ANDERSON, M. J. A. 2001. A new method for non-parametric multivariate analysis of 
variance. Austral Ecology, 26, 32-46. DOI: 10.1111/j.1442-9993.2001.01070.pp.x

ANDERSON, M. J., R. N. GORLEY \& K. R. CLARKE. 2008. PERMANOVA + for PRIMER: Guide to Software and Statistical Methods. PRIMER-E.Plymouth, U.K., 214 p.

APHA-American public health association. Standard Methods for the Examination of Water and Waste-water, 2005. 21 ed., Washington, USA.

AZEVÊDO, D. J. S., J. E. L. BARBOSA, W. I. A. GOMES, D. E. PORTO, J. C. MARQUES \& J. MOLOZZI. 2015. Diversity measures in macroinvertebrate and zooplankton communities related to the trophic status of subtropical reservoirs: Contradictory or complementary responses? Ecological Indicators, 50, 135-149. DOI: 10.1016/j.ecolind.2014.10.010 AZEVÊDO, E. L., J. E. L. BARBOSA, T. H. VIDIGAL, M. CALLISTO \& J. MOLOZZI. 2014. First record of Corbicula largillierti (Philippi 1844) in the Pararba River Basin and potential implications from water diversion of the Sao Francisco River. Biota Neotropica, 14 (4), 1-4. DOI: 10.1590/1676-0603003614

BURTON, R. F. 1983. Ionic regulation and water balance. In: SALEUDDIN, A.S.M. The Mollusca-Phisiology. Part 2. New York: Academic Press, 291-352.

CALLID, C.T. \& M. C. D. MANSUR. 2002. Corbiculidae in the Pantanal: history of invasion in southeast and central South Americana and biometrical data. Amazoniana, 17, (1-2), 153-167.

CAllistO, M. \& F. ESTEVES. 1996. Composição granulométrica do sedimento de um lago amazônico impactado por rejeito de bauxita e um lago natural. Acta limnológica Brasiliensia, 8, 115-126.

CDB - Convention on Biological Diversity -Status, impacts and trends of alien species that threaten ecosystems, habitats and species. Invasive Alien Species. 2001. CBD Technical Series No. 1,.135 p., Secretariat of the Convention on Biological Diversity, Montreal, Québec, Canada. ISBN: 92-807-2007.

CHENG, W., S. H. YEH, C. S. WANG \& J. C. CHEN. 2002. Osmotic and ionic changes in Taiwan abalone Haliotis diversi colorsuper texta at different salinity levels. Aquaculture, 203: 349-357. DOI: 10.1016/S0044-8486(01) 00606-8

DA SILVA MARTINS, D., I. L. VEITENHEIMER-MENDES \& M. C. FACCIONI-HEUSER. 2006. Aspectos morfológicos e de incubação em três espécies de Corbicula Mühlfeld, no lago Guaíba, Rio Grande do Sul, Brasil (Bivalvia, Corbiculidae). Biota Neotropica, 6 (2), 1-11. DOI: 10.1590/S167606032006000200016

ESKINAZI-SANT'ANNA, E. M., R. MENEZES, I. S. COSTA, R. PANOSSO, M. F. ARAÚJO \& J. L. ATTAYDE. 2007. Composição da comunidade zooplanctônica em reservatórios eutróficos do semiárido do Rio Grande do Norte. Oecologia Brasiliensis, 11 (3), 410-421.

FENOGLIO, S., T. BO \& M. CUCCO. 2004. Small-scale macroinvertebrate distribution in a riffle of a neotropical rainforest stream (Rio Bartola, Nicaragua). Caribbean Journal of Science, 40(2), 253-256.

FUNAKOSHI, S., T. SUZAKI, K. WADA. 1985. Salinity tolerances of marine bivalves. In: Sindermann C.J. (Ed.), Environmental Quality and Aquaculture Systems. Proceedings of the 13th US-Japan Meeting on Aquaculture, Mie, Japan, October 24-25, 1984. NOAA Technical Report NMFS 69. US Department of Commerce, National Oceanic and Atmospheric Administration, National Marine Fisheries Service, Sringfield, VA, USA, 15-16 p.

HARPER, D. 1992. Eutrophication of freshwater. London: Ed. Chapman Hall. 327 p.

HAWKING, J. H. \& F. J. SMITH. 1997. Colour guide to invertebrates of Australian inlandwater, Cooperative Research Centre for Freshwater Ecology, Albury.

KINNE, O. 1970. Marine Ecology, A comprehensive, Integrated Treatise on life in Oceans and Coastal Waters: Part 1. Enviromental Factors. New York: Wiley Interscience. 681 p. KOCK, K. N. \& C. T. WOLMARANS. 2009. Distribution and habitats of Melanoides tuberculata (Müller, 1774) and M. victoriae (Dohrn, 1865) (Mollusca: Prosobranchia: Thiaridae) in South Africa. Water SA, 35(5), 713-720. DOI: 10.4314/wsa.v35i5.49197 
LEGENDRE, P. \& M. J. ANDERSON. 1999. Distance-basedredundancy analysis: testing multispecies responses in multifactorial ecological experiments. Ecological Monography, 69 (1), 1-24. DOI: 10.1890/0012-9615 (1999) 069 [0001: DBRATM] 2.0.CO; 2

LUCCA, G. M., M. D. L. KAMADA \& J. V. LUCCA. 2012. Ocorrência de Corbicula flumineae and Melanoides tuberculata (moluscos exóticos) no córrego Retiro Saudoso, Ribeirão Preto - SP. VIII Fórum Ambiental da Alta Paulista, 8 (2), 338-347. DOI: 10.17271/19800827822012263

MACKERETH, F. J. H., J. HERON \& J. F. TALLING. 1978. Water analysis: some revised methods for limnologists. Freshwater Biological Association Scientific. Publication $N^{o} 36$. Titus Wilson \& Son Ltd, Kendall, 117 p. MALEK, E. A. \& T. C. CHENG. 1974. Medical and economic malacology. Academic Press, London, $398 \mathrm{p}$.

MANSUR, M. C. D., C. T. CALLIL, F. R. CARDOSO, C. P. SANTOS \& J. A. A. IBARRA. 2004. Uma retrospectiva e mapeamento da invasão de espécies de Corbicula (Mollusca, Bivalvia, Veneroida, Corbiculidae) oriundas do sudeste asiático, na América do Sul. In: Água de lastro e Bioinvasão (J.S.V. Silva \& R.C.C.L. Souza eds.). Interciências, Rio de Janeiro, p. 39-58.

MARCO, P. J. 1999. Invasion by the introduced aquatic snail Melanoides tuberculatus (Müller, 1774) (Gastropoda: Prosobranchia: Thiaridae) of the Rio Doce State Park, Minas Gerais, Brazil. Studies On Neotropical Fauna and Environment, 34, 186-189. DOI: 10.1076/snfe.34.3.186.8908

MARTINS-SILVA, M. J. \& M. BARROS. 2001. Occurrence and Distribution of Freshwater Mollusks in the Riacho Fundo Creek Basin, Brasília, Brazil. Revista de Biologia Tropical, 49(3), 865-870.

MARXEN, J. C., W. BECKER, D. FINKE, B. HASSE \& M. EPPLE. 2003. Early mineralization in Biomphalaria glabrata: microscopic and structural results. Journal of Molluscan Studies, 69, 113-121. DOI: 10.1093/mollus/69. 2.113

MISHRA, A. K. \& V. P. SINGH. 2010. A review of drought concepts. Journal of Hidrology, 202-216. DOI: 10.1016/j.jhydrol.2010.07.012 MUGNAI, R., J; L. NESSIMIAN \& D. F. BAPTISTA. 2010. Manual de identificação de macroinvertebrados aquáticos do estado do Rio de Janeiro. Rio de Janeiro: Technical Books Editora, $174 \mathrm{p}$.

MUSTAPHA, M. K. 2008. Assessment of the Water Quality of Oyun Reservoir, Offa, Nigeria, Using Selected Physico-Chemical Parameters. Turkish Journal of Fisheries and aquatic sciences, 8(2), 309-319.

NEWELL, R. C. \& G. M. BRANCH. 1980. The influence of temperature on the maintenance of energy balance in marine invertebrates. Advances in Marine Biology, Plymouth, 17, 329-396. DOI: 10.1016/S0065-2881(08)60304-1

PEREIRA, D., M. C. D. MANSUR \& D. M. PIMPÃO. 2012. Identificação e diferenciação dos bivalves límnicos invasores dos demais bivalves nativos do Brasil. In: MANSUR, $M$. C. D; SANTOS, C. P.; PEREIRA, D.; PAZ, I. C. P.; ZURITA, M. L. L.; RODRIGUEZ, M. T. R.; NEHRKE, M. V. \& BERGONCI, P. E. A. eds. Moluscos límnicos invasores no Brasil: biologia, prevenção e controle. Porto Alegre, Redes Editora. p.75-94.

POINTIER, J. P., R. N. INCANI, C. BALZAN, P. CHROSCIENCHOWSKI \& S. PRYPCHAN. 1994. Invasion of the rivers of the littoral central region of Venezuela by Thiaragranifera and Melanoides tuberculatus (Mollusca: Prosobranchia: Thiaridae) and the absence of Biomphalaria glabrata, snail host of Scistosoma mansoni. The Nautilus, 107 (4), 124-128.

PORTER, S. D., D. K. MUELLER, N. E. SPAHR, M. D. MUNN \& N. M. DUBROVSKY. 2008. Efficacy of algal metrics for assessing nutrient and organic enrichment in flowing Waters. Freshwater Biology, 53, 1036-1054. DOI: 10.1111/j.1365-2427.2007.01951.x

PORTO, E. R., A. D. S. SILVA, J. B. D. ANJOS, L. T. D. L. B. BRITO \& P. R. C. LOPES. 1999. Captação e aproveitamento de água de chuva na produção agrícola dos pequenos produtores do semiárido brasileiro: o que tem sido feito e como ampliar sua aplicação no campo. Centro de Pesquisa do Trópico 
Semiárido (CPATSA).

REYNA, P. B., A. G. MORAN \& M. TATIAN. 2013. Taxonomy, distribution and population structure of invasive Corbiculidae (Mollusca, Bivalvia) in the Suquía River basin, Córdoba, Argentina. Iheringia, Série Zoologia, 103(2), 77-84. DOI: 10.1590/S007347212013000200001

RICCIARDI, A. \& H. J. MACISAAC. 2000. Recent mass invasion of the North American Great Lakes by Ponto-Caspian species. Trends Ecology, 15, 62-65. DOI: 10.1016/S0169-5347 (99)01745-0

ROCHA, O., E. L. G. ESPÍNDOLA, N. FENERICH-VERANI, J. R. VERANI \& A. C. RIETZLER. 2005. Espécies invasoras em águas doces estudos de caso e propostas de manejo. Universidade Federal de São Carlos, São Carlos, 416 p.

SANTOS, C. M. \& E. M. ESKINAZI-SANT'ANNA. 2010. The introduced snail Melanoides Tuberculatus (Muller,1774) (Mollusca: Thiaridae) in aquatic ecosystems of the Brazilian Semi-arid Northeast (Piranhas-Assu River basin, State of Rio Grande do Norte). Brazilian Journal Biological, 70, 1-7. DOI: 10.1590/S1519-69842010000100003

SILVA, E.C. \& F. BARROS. 2011. Macrofauna bentônica introduzida do Brasil: lista de espécies marinhas e dulcícolas e distribuição atual. Oecologia Australis, 15(2), 326-344.

SILVA, R. E., A. L. MELO, L. H. PEREIRA \& L. F. FREDERICO. 1994. Levantamento malacológico da Bacia hidrográfica do Lago Soledade, Ouro Branco (Minas gerais). Revista do Instituto de Medicina Tropical de São Paulo, 36, 437-444. DOI: 10.1590/ S0036-46651994000500008

SUGUIO, K. 1970. Introdução à sedimentologia . São Paulo: Edgard Blucher, 1973, 317 p.
THIENGO, S. C., A. F. BARBOSA, P. M. COELHO \& M. A. FERNANDEZ. 2006. Moluscos exóticos com importância médica no Brasil. Available in: http:/www. mma. gov.br/ invasoras/capa/docs/co/silvana_carvalho.pdf.

THOMPSON, F.G. 2004. An identification manual for the freshwater snails of Florida. Gainesville: Museum of Natural History, University of Florida, $94 \mathrm{p}$.

THORNTON, K. W., B. L. KIMMEL \& F. E. PAYNE. 1990. Reservoir limnology: ecological perspectives. John Wiley \& Sons, New York.

TORRE, L. \& P. REYNA. 2013. Bivalvia, Veneroidea, Corbiculidae, Corbicula largillierti (Philippi, 1844): New distribution record in the Del Valle Central basin, Catamarca Province, Argentina. Check list, 9 (1), 165-166. DOI: 10.15560/9.1.165

TRIVINHO-STRIXINO S. 2011. Chironomidae (Insecta, Diptera, Nematocera) do Estado de São Paulo, Sudeste do Brasil. Biota neotropical. 11, 1-10. DOI: 10.1590/ S1676-06032011000500032

TRIVINHO-STRIXINO, S. \& G. STRIXINO. 1995. Larvas de Chironomidae (Diptera) do estado de São Paulo: Guia de identificação e Diagnose dos Gêneros. São Carlos-SP: PPG-ERN/UFSCAR, 229 p.

VAZ, J. F., H. M. S. TELES \& M. A. CORREA. 1986. Ocorrência no Brasil de Thiara (Melanoides) tuberculata (OF Muller, 1774) (Gastropoda, Prosobranchia), primeiro hospedeiro intermediário de Clonorchissinensis (Cobbold, 1875) (Trematoda, Plathyhelmintes). Revista de Saúde Pública, 20(4), 318-322. DOI: 10.1590/S0034-89101986000400008

WARD, H. B. \& G. C. WHIPPLE. 1959. Biologia de água doce. John Wiley and Sons. New York, $128 \mathrm{p}, 2^{\circ} \mathrm{ed}$.

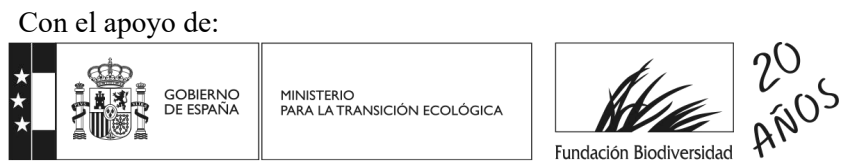

